\title{
Implementation Study of Public Policies, Synergity of Policy for Defense Area and National Area Spatial in Grati Pasuruan
}

\author{
Kasih Prihantoro ${ }^{1} \quad$ Arif Darmawan $^{1} \quad$ Zakariya $^{1} \quad$ Lukman Yudho Prakoso $^{2}$ \\ 1.FISIP Universitas 17 Agustus 1945 Surabaya, Indonesia \\ 2.Lecturers of Sea Defense Strategy of IDU, IPSC, Sentul-Bogor, Indonesia
}

\begin{abstract}
The development of a global, regional and national strategic environment has led to the development of factual and potential threats that must be faced by Indonesia. A strong defense is needed that is supported by all available resources, one of which is related to the area of defense. This research will analyze the implementation of defense areas, especially military training areas in Grati Pasuruan. Problems arise in several regions of Indonesia related to defense areas, even to the point of causing fatalities as happened in the TNI AL Grati Pasuruan training area. For this reason, this research is aimed at analyzing how the spatial planning of defense policy is currently implemented. The theory used is the theory of Van Matter and Van Horn policy implementation. The method used in this research is a qualitative method with a phenomenological approach. The results showed that the implementation of the defense area policy could not be carried out, due to the finding of inhibiting factors, namely the lack of coordination from the regional government and the Ministry of Home Affairs in planning and ratifying the regional spatial planning, resulting in overlapping in the utilization of an area. The supporting factors are that all policies related to regional spatial regulation already exist. So that in this research suggestion is to bring back an independent government agency, whose task is to coordinate and make decisions regarding spatial planning, this independent institution will act as a policy force driver in national spatial planning. As a recommendation, the Pasuruan Regency regional regulation related to spatial planning to be evaluated and an independent institution be formed immediately by strengthening policies to the operational level.
\end{abstract}

Keywords: Defense Area, Spatial Planning, Implementation

DOI: 10.7176/PPAR/9-11-04

Publication date: November $30^{\text {th }} 2019$

\section{Introduction}

The development of the global strategic environment is currently characterized by a shift in US hegemony; particularly in the Asia-Pacific region that gradually began to erode by the rapid growth in China. The United States certainly does not want an inequality of influence; because the loss of hegemony in the Asia-Pacific region will have a huge loss of impact on all aspects of the life of the United States.

China is also well worth attention, planned or not, they have transformed into a new great power that has positive and negative effects; as the growth in China has 2 (two) sides; threats and opportunities. The situation in the United States is chaotic; a kind of anti-climax of the central role of the United States in the international arena, meanwhile China's growth rate that has not been seen will stop; sooner or later it will begin to compensate for even very likely to pass through the power and influence of the United States and this is very much realized by China and other parties, both opposite and allied.

The US plan will move its focus from the Middle East to the Asia-Pacific by 2020, it is seen by placing $60 \%$ of the Navy's power in the Asia-Pacific region. They have many shipments of US fighter jets to several countries in the Pacific Ocean region, such as Thailand, India, Singapore and Australia in a purpose to strengthen the US military presence in the Pacific Ocean. This condition needs to be anticipated because Indonesia is in a bad position, choosing between 2 (two) forces; United States and China [1].

The development of this global strategic environment also influences the actual and potential threats that will be faced by Indonesia, therefore one of the focus of Indonesia's interests in the development of national defense architecture is how to realize security and peace stability in the region as an integral part of national interests, and anticipate potential and solutions overcome it[2].

In order to keep security and maintain the sovereignty of the country, the integrity of the territory of the Republic of Indonesia and keep safety of all the Indonesian people, a universal state defense system has been arranged according to the regulation; Act No. 3/2002 concerning National Defense. Article 1 point 2 of Act Number 3/2002 stated [3]: "the nature of National defense system is universal which means to involve all citizens, regions, and all other national resources, and are prepared in advance by the government and held in total, integrated, directed, and continue to uphold national sovereignty, territorial integrity and the safety of all nations from all threats ".

Regional Arrangement of National Defense has been regulated by the Republic of Indonesia Government Regulation (PP) Number 68 of 2014[4]. as an elaboration of Article 17 paragraph (7) of the Act of the Republic 
of Indonesia Number 26 of 2007 concerning in Spatial Planning [5]. This Government Regulation regulates the arrangement of the defense area which includes the Determination, Planning, Utilization and Control of Defense Areas as a guideline for the Government / Regional Government (Pemda) and TNI. Article 5 of PP 68/2014 states that "Defense Areas are determined by the Government by taking into account regional interests and defense functions".

Article 26 paragraph (1) "The Government and / or Regional Government must provide land for the development and development of the State Defense Area", paragraph (3) "The land as referred to in paragraph (1) is in accordance with the function of the Defense Area as referred to in article 6 letter a to g (military / military bases, military training areas, military installations, military test equipment and weapons areas, other explosive and dangerous storage areas, ammunition disposal areas and other dangerous defense equipment, national vital objects that are strategic, and / or air defense interests).

Article 4 states that "The implementation of the Defense Territory arrangement is carried out in an integrated manner with national territory spatial planning, provincial spatial planning and regency / city spatial planning". Thus the mandate of Government Regulation Number 68 of 2014 confirms that the Central / Provincial / Regional Government has an important role in supporting the existence of the Defense Area including facilitating the implementation of defense duties.

On the other hand, the long and medium term development in the Province / District / City is guided by the Regional Regulation (Regional Regulation) concerning the Regional Spatial Planning (RTRW) in each of the current regions, in other words that regional development must not against the Regional Regulation and the Regional Regulation itself must be in line with Government Regulation (PP). However, in some areas there are some problem with development that have not been aligned with Government Regulations, particularly related to the aspect of the national defense area, even though there was a solution but still could not solved the problem because the relocation solution offered does not meet the demands of operational needs.

Examples of several cases are; (1) the construction of the Red and White Bridge in Ambon, which is only 34 meters in height, hence it cannot be passed by large tonnage warships that have an average height of 35-45 meters to dock at the Indonesian Navy port in Halong, Ambon and offered relocation at Tawiri bay where land acquisition has not available yet and no facilities meanwhile, the operational activities must continue [6]; (2) the Makassar New Port (MNP) development plan has not been in line with the defense area, where the development has had an impact on narrowing the sea defense area of Lantamal VI and potentially increasing the sedimentation rate which accelerates siltation in the pier ponds, thereby disrupting maneuverability for elements of the operation[7], meanwhile the area outside the MNP as the replacement for sea defense area, but there is no realization although the operational activities must continue, (3) construction of the Bahtera Mas Bridge in Kendari Bay which is only 19 meters high, too low and cannot be passed by warships that will dock at the Indonesian Navy's Kendari and at this time the Southeast Sulawesi Provincial Government have been offered for relocation to the land offered by a private company[8], and there are still many other cases. These case examples are indications that the arrangement of defense areas may not yet be understood and is not yet known or not yet considered a national strategic area that needs to be given mutual attention, or generally can be hypothesized while that development in the region has not been synergized with spatial planning of defense areas.

In order to avoid development problems to occur in the regions such as the examples above that have an impact on the interests of the defense area, particularly in the maritime defense area, this is important to carry out research by paying attention to the examples of the aforementioned events, the synergy of development in regions be in accordance with the arrangement of the defense area into an important and strategic matter, so that the function of the defense area is ready to be used for the defense in order to maintain the sovereignty of the country, the integrity of the NKRI and the safety of the nation, in accordance with the mandate The 1945 Constitution and as an effort to incarnate the World Maritime Axis.

\section{Problem Formulation}

Based on the introduction above, the formulation of the problem in the current research is how the implementation of the policy on Defense Areas and Defense Area Plans, in the TNI AL Grati Pasuruan training area and how so that the objectives of spatial planning of defense areas and national spatial planning can synergize for one purpose nation and state?

\section{Methods and Theories}

This study uses qualitative methods, according to, the notion of qualitative research is research based on the philosophy of post positivism, used to examine natural conditions of objects, (as opposed to experiments) where the researcher is a key instrument, sampling data sources is done purposively and snowball, tri-anggulation (combined) collection techniques, data analysis is inductive or qualitative, and qualitative research results emphasize meaning rather than generalization. [9].

According to Polkinghorne (Creswell, 1998) Phenomenological studies illustrate the meaning of a life 
experience for some people about a concept or phenomenon. People involved in dealing with a phenomenon explore the awareness structure of human life experiences. Meanwhile, according to Husserl (Creswell, 1998) phenomenological researchers try to look for things that are necessary (essential), invariant structure (essence) or the meaning of experience that is fundamental and emphasizes the intensity of consciousness where experience consists of things that appear from the outside and things that are in each awareness based on memory, image and meaning. [10]

The theory used in this research is the theory of Van Mater and Van Horn, Van Meter and Van Horn called A Model of the Policy Implementation (1975). This implementation process is an abstraction or performance of a policy embodiment which is basically deliberately carried out to achieve high policy implementation performance that takes place in the relationship of various variables. This model presupposes that policy implementation runs linearly from political decisions, implementers and public policy performance. This model explains that policy performance is influenced by several interrelated variables, these variables, namely: Standards and policy objectives / policy measures and objectives, Resources, Characteristics of implementing organizations, Attitudes of implementers, Communication between related organizations and implementation activities , Social, economic and political environment [11]

\section{Analysis and Discussion}

The following is an analysis and discussion of defense area policies and defense area plans related to problems that occur in the Navy training area in Grati District, Pasuruan Regency, East Java Province:

4.1. Description of Problems of the Navy Training Area in Grati Pasuruan East Java The Indonesian Navy has a land area of 3,672,325 M2 located in Pasuruan Regency, East Java, and is divided into 10 villages, the following are the findings at the research locus:

4.1.1. Regional Regulations, which do not support defense interests.

As the Regional Regulation of the Pasuruan Regency Spatial Planning number 12 of 2010 period 2009 s.d. 2029 [12], the area is largely designated as a residential area.

Of the ten villages in the land owned by the Navy, only 3 villages are designated as TNI AL training areas, while the remaining 7 villages are designated as settler areas.

\subsubsection{The active role of the local government that carries out administrative activities and development activities on the Navy's training ground.}

In the Navy Training Area location, the Pasuruan Regional Government established 10 definitive villages that actively serve all administrative activities of citizens / residents including the making of ID cards / KK, birth certificates, tax payments, etc. Formation of a Village in the Land of the Graduation Training Area Pasuruh, covering an area of 3,600 Ha, 10 villages were formed so that de facto community activities could be carried out. In addition to administrative activities, the Pasuruan local government also built road infrastructure, houses of worship, markets, residents' graves and electricity installations, so that the local government seemed to legalize the encroachment of BMN land assets that had been certified by unauthorized residents, this would further complicate the Navy in solving problems.

Until now, the resolution of the spatial conflict problem has not been resolved although, several efforts have been carried out to encourage resolution, because the problem is complex and requires the intervention of other ministries to solve it, while the intruders continue to grow from the original only 82 families, currently there are up to 12,000 families, so that the function of the training area as planned by the Navy did not function as it should.

\subsection{Implementation of the Defense Area Policy in the training area in Grati Pasuruan.} 4.2.1. Policy standards and objectives / measures and policy objectives,

The defense spatial planning is directly related to the national defense strategy, and even influences the successful implementation of the defense function. Within the scope of the national defense function, the spatial planning context is managed by the government, in this case the Ministry of Defense through the Defense Area Arrangement. The implementation of spatial planning specifically for the interests of the training area in Grati Pasuruan was not optimally carried out because it overlapped with the Pasuruan District Regulation No.12 of 2010, which stipulates a portion of the training area as a residential area. Then there are thousands of people who control some of the area's assets illegally.

\subsubsection{Resource,}

The Indonesian Navy has limited personnel to supervise and protect the training area so that it is not occupied by unauthorized people. An area of more than three thousand six hundred hectares is too large to be maintained at all times. The Indonesian Navy also has a limited budget to be able to create a guardrail in the Grati Pasuruan training area, so that the training area inside has many gaps where it is easy for anyone to intend to enter. 


\subsubsection{Characteristics of implementing organizations.}

Since the enactment of Law Number 23 of 2004 concerning Regional Government. Many conflicts of interest are found between the central and regional governments. Including conflicts of interest regarding the management of the spatial area of the defense. Conflicts have also occurred in various regions. [13]

\subsubsection{The Disposition of the implementers.}

The interests of spatial planning in defense areas are for the benefit of the nation and the state which are not easily understood by regional officials who do not care about the mechanism that should exist. The local government of Pasuruan Regency still unilaterally stipulated Regulation No. 12 of 2010 concerning the spatial area of Pasuruan Regency by making part of the TNI AL Grati Pasuruan training area a residential area.

\subsubsection{Communication between organizations related to implementation activities,}

Researchers found the fact that so far the entities that are related to the use of space, using networks with a star or star system. This star communication network impacts long and complicated processes. Each entity must carry out communication with each other one by one, and the stakeholders of each entity can issue policies related to the use of space. This is the main reason for overlapping policies regarding the use of space. One room but regulated by more than one entity.

\subsubsection{Social, economic and political environment}

After the 1998 reform era and the enactment of laws on local government, Indonesia entered a new era of democracy. The new pattern of democracy by applying multi-parties has an impact on the state government system which places the regional government has a strong enough voice in fighting for its interests. But unfortunately not all voices in the interests of this region can be implemented through the right channels. There are often conflicts of interest with the central government, such as the problems related to the spatial planning that occur in Grati Pasuruan. The researcher considers it is necessary to socialize the state defense program in the Pasuruan Regency apparatus and community on the importance of national defense, which so far has indeed indicated in various fields fading. [14]

Table 1. Human Development Indeks of Pasuruan Regency 2010- [15] IPM 2010Indeks Pembangunan Manusia (Persen)20112012

\begin{tabular}{|l|c|c|c|c|c|c|c|c|}
\hline Indeks Kesehatan & 0.76 & 0.76 & 0.77 & 0.77 & 0.77 & 0.77 & 0.77 & 0.77 \\
\hline Indeks Pendidikan & 0.48 & 0.49 & 0.50 & 0.53 & 0.54 & 0.54 & 0.55 & 0.56 \\
\hline Indeks Daya Beli & 0.61 & 0.62 & 0.64 & 0.64 & 0.64 & 0.66 & 0.68 & 0.69 \\
\hline IPM & \multicolumn{5}{|c}{60.7961 .4362 .3163 .7464 .3565 .04} & 65.71 & 66.69 \\
\hline
\end{tabular}

Source: BPS of Pasuruan Regency, 2019

The table above shows that the level of education in Pasuruan is relatively low, the fact that in the research locus it was found that certain political parties exploited the generally educated community for political interests by exploiting the Grati Pasuruan problem. The interests of these political parties are exploited not only at the district level but also at the provincial and central levels.

\subsection{Synergy in terms of regulations and policies}

In the legislation on spatial planning, it is explicitly stated that the national purpose of spatial use is to realize the balance of interests of the people's welfare and security and defense, even in the elaboration regulations it is more clearly explained the purpose of spatial planning is to increase the ability to maintain a dynamic state defense and security and at the same time strengthen national integration. Regional Development will synergize with the Defense Territory if Regulations derived from each Ministry / Ministry of Defense and Regional Institutions / Governments are interrelated. From Law No. 26/2007 concerning Spatial Planning as the main legislation in spatial planning is elaborated by PP 68/2014 which regulates areas for defense purposes, and decrees PP 26/2008 which regulates areas for the benefit of business development and working area areas. PP 68/2014 decreases RWP and RRWP, where RWP and RRWP are used as a reference in preparing Provincial and Regency / city Regional Spatial Planning along with detailed plans or detailed plans, also used as an input in preparing National Spatial Planning and National Strategic Area Spatial Planning. Other derivatives of Law 26/2007 are Perda containing Provincial, Regency / City RTRW and Spatial Detail Plan (RDTR). With interrelated regulations, it is an opportunity to synchronize regional development with the Defense Territory. The synchronization of the regulation is illustrated in the figure below: 


\section{PASAL 17 TATA RUANG WILAYAH PERTAHANAN DITETAPKAN DENGAN PERATURAN}

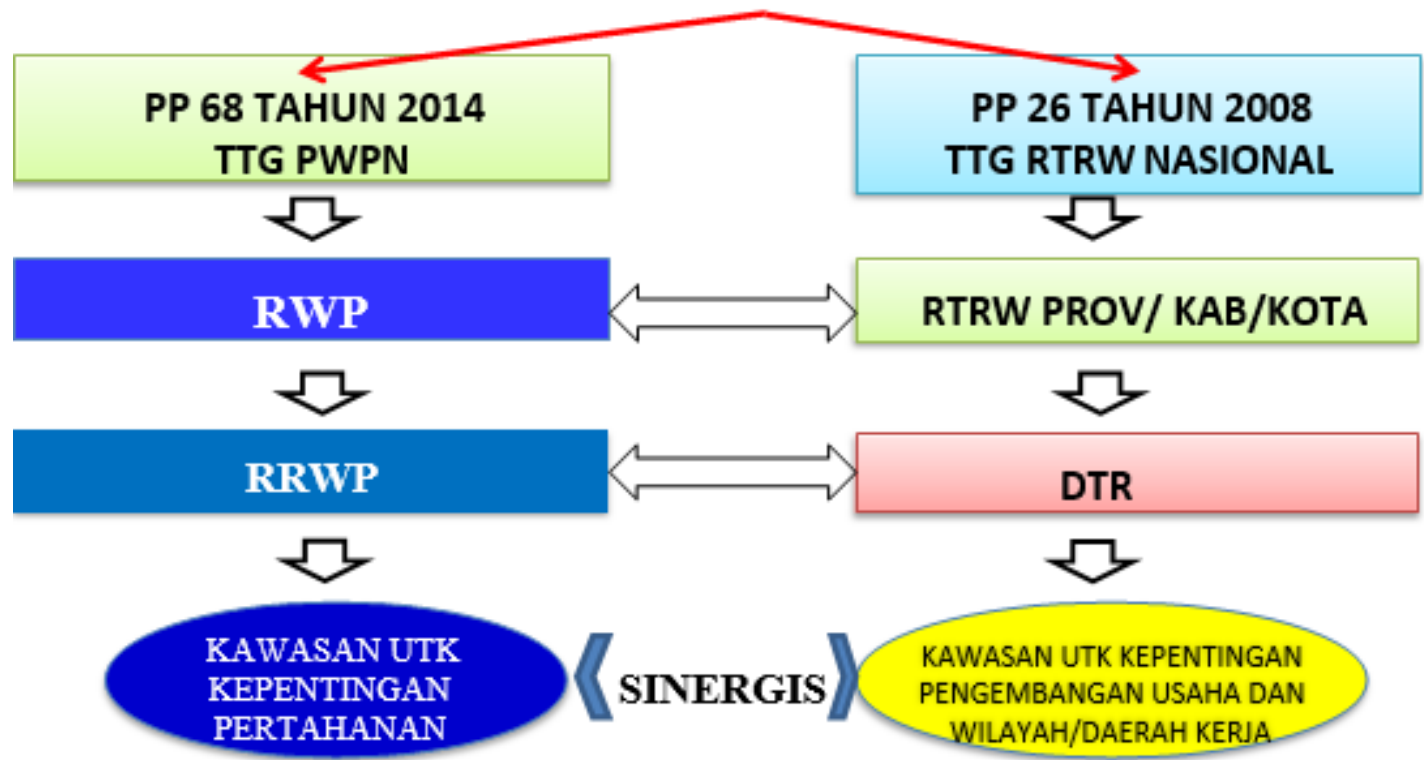

Source: Researcher data processing, 2019

Figure 1. Regulation that Synergizes Regional Regulations with Defense Areas

The problem is that not all the rules derived from PP No. 68/2014 and PP No. 26/2008 are made. RWP which is the responsibility of the Ministry of Defense already exists but is not yet perfect and has not been socialized, as well as the RRWP which is the responsibility of each force has not been made. RTRW and RDTR which are the responsibility of the Regional Government have not touched and synchronized with the issue of the Defense Area, because in the making there is no reference from the Ministry of Defense / TNI only limited to coordination represented by officials in the region who cannot bring the interests of all dimensions / forces (Land, Sea, Air), as proven by Regional Regulation No. 9 of 2009 concerning the South Sulawesi Province RTRW only includes the Wirabuana Kodam VII defense area [17]. Likewise, other regulations relating to spatial planning of defense areas also do not yet exist, for example regulations in the use of Defense Areas outside the defense function, as mandated in the same Act (Spatial Planning) Article 24 paragraph (3), that "Utilization of the Defense Area outside the defense function is carried out in accordance with the provisions of the legislation"), so that the use of the defense area has not been legally protected.

In order to integrate the Defense RTRW with the Provincial / City RTRW, the Regional Government (in this case conveyed by the South Sulawesi Province as the Speaker) suggested the following policies; [15]

1) Policy at the conceptual level, combining scientific theories for the preparation of Defense RTRW with Provincial / City RTRW using a planology approach and defense strategy tactics, through the strategy of developing spatial defense science with urban spatial planning;

2) Policy at the juridical level, preparing legislation that can support the integration of the preparation of the Defense RTRW with the Provincial / City RTRW in the framework of regional resilience, through a system empowerment strategy; and

3) Policy at the operational level, implementing the results of the scientific theoretical spatial planning and supporting the regulation of spatial planning in an integrated program of activities between the Defense RTRW and the Provincial / City RTRW, through a strategy of strengthening the institutional structure.

Efforts are made to implement these strategies carried out by implementing strategies to increase integration:

1) Efforts to introduce / socialize the RTRW of Defense to the Regional Government and the community;

2) Transforming knowledge between Defense Spatial Planning and Provincial / City Spatial Planning;

3) Making input suggestions for making Government Regulation Draft on Spatial Planning for Defense Areas;

4) Improve the quality of human resources; and

5) Dissemination of the Defense Spatial Plan to all components of the community.

After conducting analysis and discussion related to the implementation of defense areas, especially related 
to military training areas, the researchers formulated a model like the picture below in order to realize the synergy of the spatial interests of the defense area and the interests of the national spatial layout.

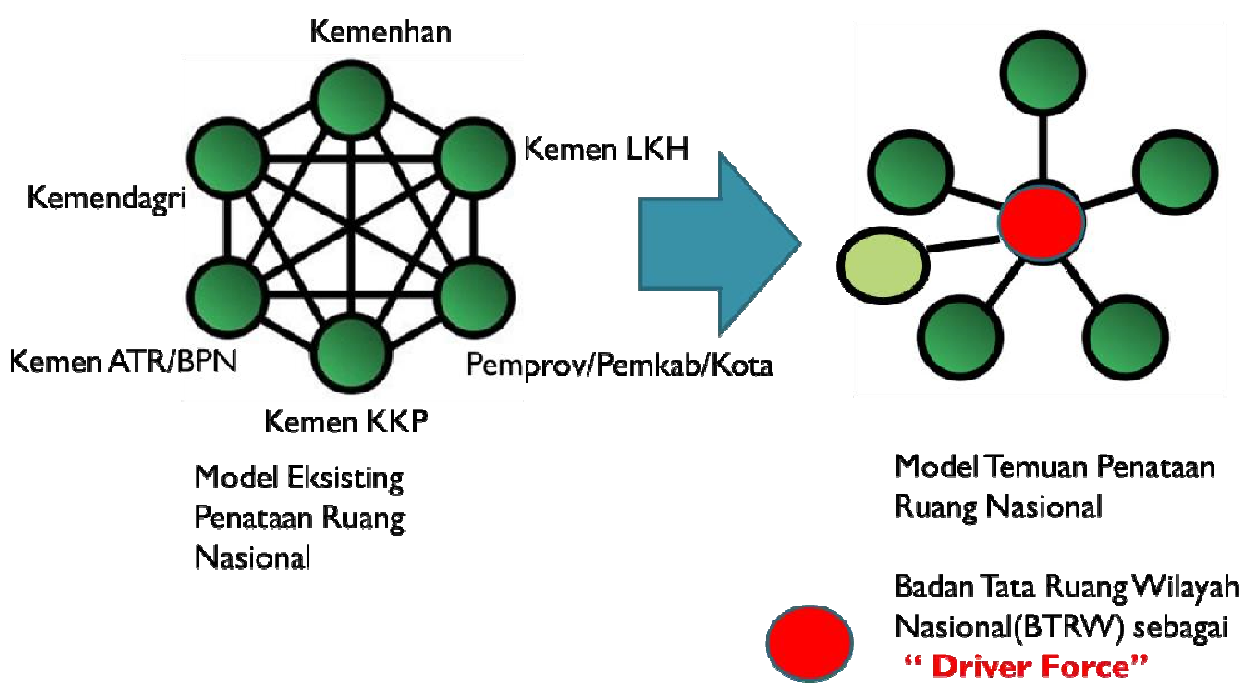

Source: Researcher Data (Kasih, 2019)

Figure 2. Spatial Planning Model Findings

Explanation from the picture above about the concept of the national spatial planning model is as follows:

The current spatial formulation model is implemented by several entities, namely in general by the Central Government and Regional Governments. These interests represent the fields of economy, environment and security and defense. The current network pattern uses the Mesh Network network pattern. Some of the drawbacks of this pattern are the wide coordination network between entities. But it is recognized that they can make decisions quickly, because each has authority. However, a very basic deficiency is like what happened in this study, where finally there is overlap in the area of policy decisions that are taken by the Central Government and Local Government.

Based on the above, the researcher formulated a concept of a national spatial planning model using the Wheel Network network. This network places an independent entity and acts neutrally in formulating a spatial planning policy which is a combination of the authority of several entities that have interests. In this way the researcher is convinced, that policies related to spatial planning can be more directed from various interests and to avoid overlapping policies can be realized. Of course, the application of the network concept of this model also has several weaknesses including the possibility of holding a hostage of interests, thus making the formulation of a long spatial planning policy.

Some things in Indonesia have also applied the Wheel Network based model concept but it is not optimal because it is not followed by policies that strengthen institutional entities that act as implementers, for example, with the existence of the Sea Safety Agency (Bakamla), Bakamla was originally a coordinating body. To address the many overlaps related to law enforcement authority at sea, it is hoped that Bakamla can become an entity that has the Single Agent Multi Task function.

However, due to the policy of the Presidential Decree which underlies the existence of Bakamla is not followed by strengthening Bakamla as a Driver Force, what is happening now is that Bakamla is adding to the complexity of the problem of law enforcement at sea along with other entities that previously existed. Actually, law enforcement representatives at sea are already included in the composition of Bakamla, but they are not effective because of the weak basic of their policies.

Seeing the problems that occur with Bakamla, researchers provide a prerequisite that the Wheel Network system by placing one entity as a Driver Force can only be implemented if, the system built is strengthened with other policies. Which places the Driver Force entity as the only unit that can issue policies related to the expected interests in spatial planning.

\section{Closing}

\subsection{Conclusion}

The implementation of spatial planning for defense areas, especially related to military training areas in Grati Pasuruan, is not optimal due to overlapping policies with Regional Regulation No.12 of 2010 concerning the spatial layout of Pasuruan Regency, which sets part of the Grati Pasuruan training area as a settlement area. Some areas of military training are also illegally occupied by thousands of residents. So that the findings of this study in order to create a synergy between the interests of defense spatial planning and national spatial planning, 
an independent institution must be formed which acts as a driver force with the Wheel Network network, in making policies related to spatial planning.

\subsection{Recommendation}

As a recommendation in this study is that Pasuruan Regional Regulation No.12 of 2010 concerning Regional Spatial Planning for Evaluation immediately. Independent institutions that have the function of deiver force must be immediately formed by reinforcing operational policies on entities related to the use of space.

\section{Daftar Pustaka:}

[1] Suhirwan and L Y Prakoso (2019), Defense strategy at sea handling of Transnational Organized Crime (TNOC) in Nunukan Indonesia's national sea border, Published under licence by IOP Publishing Ltd IOPConferenceSeries:EarthandEnvironmentalScience,Volume339,conference1

[2] S Suhirwan, LY Prakoso (2019), Forum Maritim Kunci Sukses Penanggulangan Ancaman Asimetris di Selat Sunda, - Seminar dan Lokakarya Kualitatif Indonesia 2019

[3] UU Nomor 3/2002 tentang Pertahanan Negara.

[4] Peraturan Pemerintah (PP) Republik Indonesia Nomor 68 Tahun 2014

[5] Undang-Undang Republik Indonesia Nomor 26 Tahun 2007 tentang Penataan Ruang

[6] Kemhan (2015). Surat Direktorat Jenderal Kekuatan Pertahanan kepada Menteri Pertahanan, tanggal 26 Maret 2015 tentang tanggapan dan Saran Rencana Pembangunan Dermaga Tawiri TNI AL Beserta Sarana dan Prasarananya.

[7] Lantamal VI (2016). Kajian tentang Pengaruh Pembangunan Makassar New Port dan Dampaknya Bagi TNI AL/Lantamal VI.

[8] Mabesal (2017). Hasil Survei Relokasi Dermaga Baru Lanal Kendari.

[9] Sugiyono (2009), Metode Penelitian Kuantitatif, Kualitatif dan R\&D, Bandung :Alfabeta. Hal: 15

[10] Creswell, J. . (2007). Qualitative Inquiry \& Research Design: Choosing Among Five Approaches, 2nd ed. California : Sage Publication. Hal: 63

[11] Carl Van Horn dan Donal Van Meter , 1975, Model-model dalam Kebijakan Implementasi, yongyakarta

[12] Perda Tata Ruang Wilayah Kabupaten Pasuruan Nomor 12 tahun 2010 periode 2009 s.d. 2029.

[13] Undang-undang No.23 Tahun 2004 Tentang Pemerintah Daerah

[14] Lukman Yudho Prakoso, Suhirwan 2, Gerald Theodorus L. Toruan, etc (2019), Defence State Model for Facing Threats of Radicalism and Terrorism in Indonesian Higher Education, The 3th Indonesia International Defense Sciense Seminar, 2019. Volume 2

[14] Kabupaten Pasurun Dalam Angka, 2019

[15] Kepala Dinas SDA, Ciptakarya dan Tataruang Provinsi Sulsel (2018). Bahan Paparan pada Pra FGD TNI AL Tahun 2018. 